can only be found by reference to the general index. When found, the species descriptions are clear and concise, and notes on host range, distribution and synonomy are given together with a valuable list of the collections examined by the author. The fact that the work is based on 1,200 collections actually examined by Wehmeyer gives a consistent basis for the determination of the taxa. On the other hand, little attention has been paid to the findings of contemporary workers in the group. No direct comparison is made with the work of Muller or Webster, and while Drechsler's work on the graminicolous Helminthosporium species is mentioned, the nomenclature of the perfect states (Pyrenophora, Drechslera) is not accepted, and these species are listed as synonyms of Pleospora trichostoma.

The book is well-illustrated with line-drawings and photomicrographs of many of the species. Prof. Wehmeyer is to be congratulated on producing a hand-book which makes a major contribution to our knowledge of this large and difficult group of Pleosporales. It is an essential tool for anyone working on the Ascomycetes.

C. Воотн

\section{FRESHWATER AQUARIUM FISHES}

\section{Freshwater Fishes of the World}

By Dr. Günther Sterba. Translated and revised by Dr. Denys W. Tucker. Pp. $878+192$ plates. (London: Vista Books, Longacre Press, Ltd., 1962.) 70s. net.

$\mathrm{P}$ ROF. STERBA wrote his book for the serious aquarist, and it is in this context that one must evaluate it and seek comparisons. But since behaviour investigations are becoming increasingly prominent in the ichthyological literature its value to the zoologist is also involved. Sterba's intention is to provide basic data on the identification and aquarium biology of some 1,300 species of freshwater fishes which have, at somo time or other, been introduced into aquarist circles. In this respect the book is unique, particularly since nearly all the species are illustrated, either by line-drawings or in half-tone or colour photographs. The publishers, however, are too exultant when they declare, in the blurb, that it is "... the first major handbook on this subject in English". It is not; W. T. Innes's Exotic Aquarium Fishes (1935) is a worthy ancestor.

After a concise introductory chapter on the counts, measurements and other morphological characters used in identifying fishes, and a brief introduction to nomenclature and classification, there follow the specific descriptions. These are arranged in families grouped into Regan's classification of the higher categories. Each family is given a very clear distribution map and a broad outline of its characters, both morphological and ecological, the former confined to superficial characters readily seen in the living fish. For each species there are notes on distribution (some errors here), a few meristic characters, details of colour, notes on its ecology in aquaria and, occasionally, remarks on its biology in Nature. The comments on its well-being in vitro appear detailed and practical; particular attention is given to lbreeding habits and requirements. The book does not deal with fish diseases or setting up an aquarium.

Since an aquarist is not likely to kill off a specimen he wishes to identify, it has not been possible to provide keys, even to the families. Thus, if the book is used to identify a fish the method used will be primarily that of thumbing through the illustrations. The few 'specific' characters given in the text (apart from colour notes) are therefore of restricted value unless a corpse is available. Even then they will bo trenchant only in certain groups. The line-drawings generally fulfil their purpose admirably, particularly since they show a happy tempering of the often rather bleak scientific illustration with a certain impressionistic licence. It is a pity then that the artist was unable to cope with oral barbels, especially in the Cyprinidae. Figures of these species (and also of some eatfishes) are the poorest in the book and are definitely misleading in many cases. The photographs are of a very high standard and have reproduced better in this edition than in the original. On the whole, the relevant linedrawings are placed near the text references, but the plates are generally several pages distant. It is irritating to find colour plates of tooth carps in the section dealing with armoured catfishes and even more disconcerting to find sequential photographs of spawning activities interrupted by several pages of unrelated text.

Taxonomists will doubtless find fault with the nomenclature of certain groups within their own specialized fields. Regrettable though these errors are, they are inevitable in a book of this scope produced by a single author. The translator, Dr. D. W. Tucker, has attempted to ameliorate the situation by correcting some of the more commonly perpetuated mistakes which occurred in the original, but the nomenclature of certain groups (for example the Characidae) is still rickety.

The English edition scores over its German counterpart by the addition of several species, in the extensive and annotated bibliography, and by Dr. Tucker's characteristically informative and outspoken preface. The latter could be read with profit by any Ph.D. student who is casting around for a research problem involving experimental work on fishes. Later, when he has launched out on his problem, he will find Sterba an indispensable source of information on the maintenance of his animals. There is also much that can fascinate and inform the general zoologist, particularly in the field of zoogeography. For anyone concerned with problems of body-form or coloration the plates and figures should prove provocative. Cortainly it is a book that a student could browse through profitably, bearing in mind that it covers slightly more than a twentieth of all the known fish species and certainly not all the freshwater species either, as its title in translation might imply.

Freshwater Fishes of the World has its blemishes, but these should not be allowed to detract from its considerable value. In the field of aquarium literature it is very good, and without this field it should not be ignored as a reference work to many aspects of ichthyology.

\section{P. H. Greenwood}

\section{HUMAN ANATOMY}

\section{Gray's Anatomy: Descriptive and Applied}

Edited by Prof. D. V. Davies and Prof. F. Davies. 33rd edition. Pp. xv + 1632. (London: Longmans, Green and Co., Ltd., 1962.) $150 s$.

A LL connected with the publication of this, the most A recent, edition of Gray's are to be congratulated. It might, however, seem at first appearances to be 'the mixture as before', since the form, order and many of the illustrations are familiar. However, substantial revisions have been made in the sections of histology, angiology and neurology. Throughout the text, changes, some minor, but all significant, indicate awareness of the dynamic nature of a subject too often regarded as dead. The new figures are helpful; there are a few discrepancies between text and figures, for example the Renshaw cell is mentioned several times in the text but is not depicted in the diagrams. The loss of the tracings of the outlines of the skull of a child between the ages of three months and seven years is regrettable, for these were an impressive illustration of the co-ordinated destruction and formation of bone during growth.

The book defies simplo classification. The section on embryology is a comprehensive and commendably brief text-book; the greater part is a sound, practical and 